\title{
Under the Gaze of Double Critique: De-colonisation, De-sacralisation and the Orphan Book
}

\author{
Joshua Sabih
}

\begin{abstract}
Instead of the orientalist reformist paradigm as frame and episteme, Khatibi proposes a theory of double critique, critical liminality that targets, in a bi-directional movement, a Eurocentric or Orientalist discourse and an ethnocentric local discourse. Three critical concepts, constitutive of the theory of double critique: decolonisation, desacralisation and the orphan book are operative in Khatibi's analysis of Orientalism, identity, and the issue of origin. As a professional outsider, Khatibi follows conceptually and methodologically the rules of the epistemological critique in an enunciation of negotiation, not of negation; a site of hybridity.
\end{abstract}

This limited knowledge will allow me perhaps to add that the founding of the Muhammadan religion seems to me to be an abbreviated repetition of the Jewish one, in imitation of which it made its appearance. (Freud, 1967:177).

In a word, it can be said that Islam is an empty place in the theory of psychoanalysis. (Khatibi, (2002:237) ${ }^{1}$

Toute religion, toute culture, toute communauté de mémoire ou de langue ne peut être Soi à son commencement, ne peut venir à Soi avant d'avoir fait l'épreuve de l'autre et de l'Étranger. (Benslama, 2002:31)

\section{Curse of affiliation: hermeneutical conflict}

The question of how does and/or should a native Muslim intellectual (mutaqqaf), thinker (mufakkir) and religious scholar ('älim/faqīh) ${ }^{3}$

\footnotetext{
${ }^{1}$ As indicated by Khatibi himself this article appeared for the first time in the journal Les Temps Modernes, in October 1977 under the title "Le Maghreb comme horizon de pensée", and re-edited later in his book Maghreb Pluriel in 1983. I should also indicate that all translations into English are mine.

2 "Does" and "should" are two modes of action. While the first is an actionas-process, the second is action-as-deontology.

3 Terms "intellectual" (mutaqqaf), "thinker" (mufakkir) and "religious scholar" ('älim/ faqīh) are three heterogeneous - though interdependent categories of the post-Nahda thought. These categories are framed within a
} 
approach islam ${ }^{4}$ and the Qur'ān - a foundational text of Islamic religion and Arab-Islamic civilisation - touches upon what I call here the curse of affiliation (origin) of the thinking subject in its relation to the object of study: Islamic Studies, and how one should "evaluate" and "categorise" what they say about this object of study, i.e., how we today should/ought approach this vast domain of utterances/discourses - knowing very well the intricacies of the task at hand - that these three categories and agents produce on their proper cultural heritage (turāt ). In other words, the way this issue has been articulated since the beginning of the Arab Nahda in the second half of the 19th

complex network of relationships that are structured locally and transnationally.

${ }^{4}$ The position taken in this article is that the term islam is written with a lowercase (i). However, I will not alter the orthography of the term Islam in quoted references. This is not a grammatical mistake, but purposefully a deconstruction of the grammaticalised - canonised - essentialisation of the orthodox representation of islam, (the Islam, the One, the Arabic, etc.). On this point, see my discussion of Khatibi on the orphan book in this article. The use of critical language by the critical discourse begins in how we trans-scribe this representation - as embedded trans-lation - into a hybrid site, a site of negotiation, not of negation (Bhabha 2004). Cf. my unpublished paper "Transcription as an embedded translation: Arabic \& French in Driss Chraibi's Novels, in Second Writers' and Literary Translators' International Congress, WALTIC 2010 Congress, Turkey, and my upcoming book together with a student of mine, Jacob Knak Christensen, a promising scholar in Judaeo-Arabic Studies, Transliteration as embedded translation: the Jew, the Arab in Hybrid Arabic (2016). Khatibi speaks about "the possibility of requestioning everything in islam...The islam of the Indonesian, the islam of the Sudanese and the islam of the Moroccan are not the same. There is a rift in the unity of language and believes: The Qur'ān is not the sole paradigm that structures the imaginary and thought (by the Arabic language), and at the same time structures society and the Islamic polis. There is a rift. A rift which is perhaps striking in the case of Indonesia, Malaysia...There is a scission between the founding myth in the Qur'ānic text - a myth that is hardly known - and the founding myths of people's mythologies - Indonesian, Malay." (Khatibi 2002:433). The impossibility of origin is due to the fact that origin is not palimpsestuous, which presupposes an origin (hyper-) and copies (hypo-), but translational (Bloom, 1973; Genette, 1982). Binary origin/copy expresses the hegemonic of the Arab/Arabic in its relation to the nonArab/Arabic. The same applies to the binary jăhiliya / islam. The latter is conceived in the mythic account of origin as a negation of the former. This negation is emulated / copied / mimicked in the fundamentalist discourse as a prerequisite of the true faith. There is however, a crisis of naming in Western and Islamic research traditions with regard to this study-object that is called Islam/islam. Crisis of naming - a paradox of an irreducible Islam (theology of the One) and a plural islam (islams) - that still inhabits the descriptive language of what Benslama calls "war of subjectivities". I see in Bergo and Smith's re-use of Cohen and Zagury-Orly's French term judéités in the English translation "Judeities: Questions for Jacques Derrida" an attempt to solve the tension between the terms: judaism, jewishness etc. On this issue see Derrida's input with regard to Yerushalmi's discussion of the two terms judaism, jewishness. (Derrida and Pernowitz, 1995; Bergo, Zagury-Orly \& Cohen, 2007; Derrida, 2014) I must admit that addressing this issue should be a priority for modern critical thought! Beginning with introducing neologisms islam, islams, we should be consistent in our use of them in the manner of Khatibi's double critique. (Cf. Azameh, 1993; Benslama, 2002) 
century - despite how odd this may sound - is an orientalist issue which has, paradoxically, been mimetically internalized - and since then reiterated- by essentialist Muslims themselves, and to which, inevitably, critical thought (al-fikr al-naqdī) of all ideological affiliations have to relate: two types of affiliations/genealogiesmutually exclusive - are sustained: faith/tradition versus scientificity/modernity ${ }^{5}$. Arkoun (1985:95) has rightly noticed that in most of Muslims' reactions, polemical in character, to Orientalism there is one given presumption: "the affiliation of the Muslim community confers a particular epistemological validity to which nonMuslims have no access with regard to all discourses on Islam as religion, culture and history."

As we shall see later, it is quite common that both essentialist discourses, Islamic (whether religious or nationalist) and orientalist ${ }^{6}$, harbour a feeling of suspicion towards native Muslim researchers whose critical discourse follows the rules of the epistemological criticism; the latter group is simply disqualified. They are considered as neither western nor orientals ${ }^{7}$. (Gunther, 2013, Arkoun, 2007) Actually, the critical discourse - a hybrid site - of contemporary "native Muslim intellectuals ${ }^{8}$ - dare, in one simultaneous double act, to break away a) from being merely an orientalist objectified subject, lacking any scientific (critical) language, "native informant" (Spivak 1999), and b) from what Arkoun calls dogmatic enclosure (Arkoun 2007). Breaking away should be understood as a process. That is being in the process of breaking away. Instantaneous breaks, however, make everything fall into the abyss.

\footnotetext{
${ }^{5}$ The issue of how this issue was posed in the formative and classical periods of islam is beyond the scope of this article. The thing that the reader should retain here is that Arab-Islamic literature attests to the figure and profession of the intellectual - independent and critical one in particular. Besides, Qur' ānic archive has preserved the views of Arabs: Christians, Jews, Hanifs, and Pagans etc.- who contested Muhammad's prophethood on various important points - are actually recorded. On the notion of "intellectual" in the Middle Ages see (Le Goff, 1993; Urvoy, 1996)

${ }^{6}$ The term "orientalist" used in this article refers to western discourse(s) about the orient: Body of knowledge, epistemology, ideology, worldview etc.

${ }^{7}$ In another context, Derrida re-asks the question that J. H. Yerushalmi asks in his book Moses: Judaism Terminable and Interminable: "Professor Freud, at this point I find it futile to ask whether, genetically or structurally, psychoanalysis is really a Jewish science; that we shall know, if it is at all knowable, only when much future work has been done. Much will depend, of course, on how the very terms Jewish and science are to be defined."'(Quoted in Derrida and Prenowitz, 1995:28). Is psychoanalysis a Jewish science? Khatibi takes his cue from this very question in his article that I am presenting/discussing in this paper: "Frontiers: Between Psychoanalysis and islam”. [Emphasis is mine]

${ }^{8}$ For the sake of simplicity, I shall use the terms intellectual and thinker interchangeably, and in opposition to the religious scholar, whom I call cleric. When I add the qualifier critical to the terms intellectual and thinker, I refer to a category of post-modernist/postcolonial thought that challenges the very notion of affiliation - or what Freud calls " family romance".
} 
Before attending to Khatibi's critical discourse on French orientalism and exercising psychoanalysis as frontierial ${ }^{9}$ position in the language and exercise of a profession, I would like to visit- as a frontierial scholar myself 10_ this seems-to-be-forever-debated issue: this seemingly inescapable curse of affiliation - palimpsestuous text: origin and its duplications - that critical "native Muslim" intellectuals, whom both foundational metaphysics and politics of identity have condemned them to, have tried to debunk; the irreducible essence of islam as absolute-other. In general terms - knowing too well how dangerous and slippery this can be and lead to - any critical intellectual (Muslim genealogy: the racial, ethnic and the religious are amalgamated) - is construed/imagined as absolute-other trapped in Sisyphean state. In this optic, any act of decolonisation and desacralisation that critical thinkers like $\mathrm{Khatibi}^{11}$ - as one of these rare theoreticians and practitioner of critique double - are engaged in is seen as a meaningless act of repetition and borrowing: hence the notion of islamicising foreign knowledge. ${ }^{12}$ Nothing new under the sun says the biblical Solomon! The gatekeepers of both Western scholars on islam in the name of science and objectivity, and Muslim clerics in the name of orthodoxy brand as a unscientific/heretic any critical (discourse) about any (Islamic topic) that trespasses the

\footnotetext{
${ }^{9}$ I have chosen to render the French adjective frontalier by frontierial - not frontier-like, or boundary - because the last terms do not do justice to the meaning of the French term: "Qui habite une région voisine d'une frontière, et, en particulier, qui va travailler chaque jour au-delà de cette frontière." ("A person who lives in a region neighbouring a border, and, in particular, someone who crosses that border every day to go to work") Larousse. A frontierial critique is understood as double critique in the sense of critical liminality. See Raja Rhouni's use of Khatibi's double critique as critical liminality in her analysis of the Work of Fatima Mernissi. (Rhouni, 2010)

10 On this autobiographical note, I would like to draw the attention of the reader that I too bear the mark of this curse of affiliation(s) in my body (-ies), my tongue(s), and my trans-disciplinary profession. It is not strange that my take on problems and issues of Orientalism, post-colonial and critical thinking is reflexive. It breaks away - as I identify myself with the stance that reflexive thinkers take on - with traditional thought. (cf. Khatibi, 2002)

${ }^{11}$ Abdelkébir al-Khatibi (Khatibi 1938-2009) is a prolific Moroccan thinker, philosopher sociologist, poet, novelist and activist. He has studied sociology at the University of Sorbonne in Paris. He earned his doctorate in 1968. Although he wrote almost exclusively in French, he was well versed in Arabic. Regarding his bibliography see for instance his Oeuvres complètes in three volumes: vol.1: novels, vol.2: poetry, vol.3: essays, which were published in 2008. He was of course one of the leading Arab translational/trans-national thinkers who worked on various fronts: the political, the cultural, the academic, the literary, the social etc. Already in 1968, Khatibi was engaged in the postcolonial debate that Marxist intellectuals inaugurated in the movement around the journal Souffles. Cf. Sefrioui 2013, Bonn 1999) ${ }^{12}$ See in this paper, Khatibi's and Arkoun's discussions of the following notions: ideological adaptation of metaphysical concepts, and the polemical aspects of the Islamic discourses respectively. As indicated in note 7 (supra), Khatibi's discussion of Freud's psychoanalysis is not intended as an islamicising project.
} 
"lies"13, the norms (methodology) and boundaries (subject matter) that are paradoxically agreed upon. It goes without saying that native intellectuals and religious scholars - clerics - are not and have never been a homogenous group. In the same vein, we know that ArabIslamic thought has never been exclusively religious or the sole property of a particular group. This is not a question of genre, but rather a question of discourses and representations, their conflictual relations, and their social and political agency.

The narrativisation of Arab-Islamic modern thought takes its cue from a Eurocentric narrative of Western Modernity being universalised in a double violent act - Bonaparte's invasion of Egypt in 1798. Bonaparte came to Egypt with an army of soldiers and men of learning. The Arab Orient became an object of military, economic and political subjugation, and an object of study (hence Orientalism as a discourse on the Orient). This historical event is mythologized as the beginning and catalyser of modern Arab-Islamic thought. A new chronology in evenemential historiography: a pre-modern and modern Arab-Islamic thought ${ }^{14}$. A "tailored" modernity began as process of a much less discussed dichotomy: the translatable and the untranslatable ${ }^{15}$. A new problematic was born: the term-pair așāla wal-mu'āsara (authenticity and modernity). In fact, the term mu'assara denotes the idea of contemporaneity. That is being in the time lived as contemporaneity, and often is construed discursively as presence versus absence, a binary of opposition and hegemony: Western presence and Muslim absence; two opposing times, world views, discursive modes that are for ever essentialised and essentialising. Cultural differences, in these logicising discourses, are

${ }^{13}$ Bhabha speaks of this "lie" in the chapter "Articulating the Archaic: Cultural difference and colonial nonsense" as follows: "If a Muslim is coerced into speaking a Christian truth he denies the logic of his senses.... A part of like "folly" that is untranslatable, inexplicable, unknowable, yet repeatedly transmitted in the name of the native. What emerges in these lies that never speak the "whole" truth, come to be circulated from mouth to mouth, book to book, is the institutionalisation of a very specific discursive form of paranoia." (Bhabha, 2004:197).

${ }^{14}$ Worth mentioning that the attempt to project European history on ArabIslamic history in the name of historicity has utterly failed. Besides positivism, classical Marxism - or the Eurocentric reading of Marxism and their proponents in the Arab world- has seen the universalization of Capitalism as a necessary and an unavoidable historical phase. Once again the colonial discourse has been reproduced - auto-orientalism or domestic orientalism! As we know now that capitalism has not been universalised in the Arab World, but rather a new division of worlds another different relations of production.

15 For instance, Samah Selim, in her discussion of the politics of translation in Egypt in the 19th 1nd 20th centuries distinguishes between "authorised version of texts, which is tied up with power" and free zone (unauthorized) version of texts (detective novel or what one calls popular literature); a genrebased translation according to which one finds formal (state sponsored) and informal (individual) translations. The latter, "unlike scientific ones, were not funded and organized by the state, but were instead "clandestine, meandering, and quite mischievous.” (mlynxqualey, 2015:1). Cf. Selim, 2010) 
enunciated in terms of power politics: dialectics of permanent negation; a sort of theology of election, according to which only one group, the detainer of the absolute truth will be saved ${ }^{16}$. The emergence of modern Islamic Studies, inter alia, was conceived within this socio-political frame of asymmetrical power-relations. It is, therefore, of an utmost importance that we recognise this fact, obvious to all who wants to see it: the one, who does or should deal with this body of knowledge, does not escape these conditions of "birth", the consequence of which represented and articulated in three kinds of discourses: Islamic, Orientalist, and Critical. While the first two represent two sides of the same coin: essentialising discourse that reproduce and sustain a structural separation between what is Islamic and what is Western, the latter, notwithstanding, tends to follow conceptually and methodologically the rules of the epistemological critique in an enunciation of negotiation - not negation; a site of hybridity.

In this paper, I intend to focus on the Khatibi's double critique as a reflexive theory and praxis of decolonisation, desacralisation and a labour of incessant de-essentialisation of all sorts of affiliations, "targeting both a Eurocentric or Orientalist discourse and an ethnocentric local discourse." (Rhouni, 2008:47) In the last part of this paper, I shall direct my gaze - that of an accomplice - to Khatibi's notion of Muhammad as the orphan book through an embroidering and embroidered ${ }^{17}$ double reading - his and mine, reading and rereading as thought-other ${ }^{18}$ - of Freud's enunciation on "Islam" as an

16 This theology of the elected one has been crystallized by the dogmatic reason which characterises the religious discourse: Jewish, Christian, Muslim etc.

${ }^{17}$ Here, we are presented for and in the presence of a critical concept. Before its conceptualisation as such, it used to be- and still is - a metaphorisation of the bilingual: Arabic-Hebrew in Judaeo-Moroccan poetry. A minority discourse on "being together as difference" and "in space architecture and language, which the term t.r.z. ( passive participle: matrüz: embroidered) in both Arabic and Moroccan lexicographies convey. The idea of painstakingly making something - a cloth, building, morals, and utterance - looks differently beautiful is inherent in the term matrūz: embroidered. For instance, embroidering a cloth by sewing patterns on it with thread transforms the cloth into something else: handkerchief, dress, etc. I have conceptualized this term as a critical liminality in my work on Sami Shalom Chetrit's political poetry and Matrūz identity. (Sabih, 2009).

${ }^{18}$ What does reading, re-reading as thought-other mean? Khatibi presents this double reading in his article "La Sexualité selon le Coran" (Sexuality according the Qur'an) in which he sets his reading as a reading of another reading or reading of another's reading. Here, he refers to his reading of the Qur'ān and his reading of Arkoun's reading of the Qur'an. Khatibi's reading consists of two distinct reading events:

1. Reading as a suspension of "the immense archive of glosses and exegesis on and from the Qur'an." In order words Khatibi wants to read the Qur'ān apart from the prophet's Hadīt or the Bible. Suspension in the act of reading does not imply its rejection or its negation. He chooses the "Qur'anic perspective in itself with regard to the issue of 
"abbreviated repetition" and an "imitation" of Jewish religion. Reading Khatibi is not an easy task. Every single word throws its reader to a hierarchy of genres, references, times, places, theories and languages. For this reason, I need to map once again a typology of various literary systems and their relational interdependence in order for the reader to understand where this double critique stands.

To sum up, one notices two prominent discourses: 1) a mimetic: which "mimics methods, conceptual devices, modes of composition and argumentation of Western scientific discourse and its logocentrism into a kind of auto-orientalist discourse that reproduces the same binary oppositions and their inter-negating relations: Orient/West, religion/scientificity, pre-modern/modern etc., 2) a bidirectional critical liminality that moves from and into the margin. In this movement, it de-centres all centres and itself, that the very idea of centrism. This theory of double critique, which contains the notion of mise en crise (putting into crisis /challenging), is often forgotten. Critique as putting in crisis both itself and the object under its scrutiny. In this sense too, critique is double: critique of its intrinsic law and of societal law." (Khatibi 1981:319) ${ }^{19}$

The difference between the two can be demonstrated, for instance, in how Taha Hussein's and Khatibi's critical approaches to the Qur'ān. Both were attentive to the theoretical and methodological challenges that the critical intellectual in a modern setting were facing. The result: two positions/discourses: a mimetic reading ${ }^{20}$ and double critique reading, a pensée-autre. To illustrate the latter point further - and in conjunction with our main topic - the Qur'ānic text has become - sometimes inadvertently - for a great number of

sexuality - not sex - without any reference - or seldom - to other monotheistic texts." (Khatibi, 2002:241). Suspension of Hadīt - in double-crtique reading of the Qur'ān - is a deconstruction of the very concept of sacralisation of meaning as self-generating - latent in Orthodoxy's epistemology, and a suspension of the biblical debt": The Bible is imagined as orgin and the Qur'ān as a borrower/borrowing.

2. Reading as actualisation of other critical readings, as for instance Arkoun's reading, according to which "a programme of reading consists of three moments: a) a linguistic moment that will allow for a descovery of the covert order beneath the fragmented overt structure; b) an anthropoligical moment which will consist in recognsing the language of the mythical structure in the Qur'an; and c) a historical content in which the impact and limitations of logico-lexicographic exegeses and imaginative exegeses that Muslims have attemped so far will be defined." (ibid.) (Cf. Arkoun 1970, 2001).

19 “ L'idée souvent oubliée d'une mise en crise. La critique comme mise en crise á la fois d'elle même et de l'objet dont elle s'occupe...En ce sens aussi, la critique est double: critique de sa loi intrinsèque, et celle de la loi sociétale." (Khatibi, 2002: 319). This text was first published in 1981, and later in 2002.

${ }^{20}$ The same applies to al-Jābirî's comprehensive reading (commentary) of the Qur'ān. He was the only modern critical thinker and philosopher who has produced a four-volumes tafsir, in which he tried to reconstruct the "historicity" of the Qur'ān as tanzīl, lost in classical exegesis of the Qur'ān as muṣhaf (codified Qur'ānic text). 
contemporary Arab thinkers an existentialist question, a hermeneutical battlefield on which these intellectuals have been trying to recover the Qur'ān from its self-imposing custodians religious clerics - and restore it back to what it is - a palimpsest and an origin-less translation, a polyphonic text accessible by and to all. The common concern - besides ideology and politics - for these committed intellectuals is, primarily, issues of epistemology, methodology, and identity. In the book $f_{\grave{l}}$ al-š́i ' $r$ al-jāhilī (about jāhilī poetry) ${ }^{21}$ - if one should choose a beginning among many beginnings ${ }^{22}$ - the Egyptian, saint Simonian and Descartian positivist, Taha Hussein called upon Arabs to set aside their emotional bias and engage, instead, in a critical study of their literary and religious heritage - (al-ši 'r al-jāhilī). He meant that Arabs should do it as if they were strangers (occidentals) $^{23}$. (Hussein, 1926) The most vocal reactions - that have been accredited the privileged status of authenticity and representativeness ever since - were the reactionary voices of Muslim Orthodoxy $y^{24}$. These authenticity and representativeness should be reflected in epistemology, methodology and identity in opposition to

${ }^{21}$ Well! This is the crux of the matter. I am trying to avoid the term preIslamic that has been standardised in modern scholarship. The main idea of Taha Hussein is that if one should find a text that could tell us anything trustworthy about Arab Jāhilī society, the Qur'ān would be the right one, not the so-called "pre-Islamic" poetry. My position is that the Qur'ān becomes a Jāhilī product, a frontierial text, and a discourse - a very significant one I must add - on this yet-to-be chartered Jāhilì society.

${ }^{22}$ Beginning does not mean origin, but simply an emerging. Or as Gil Anidjar has articulated it: "In the beginning, there was no beginning" (Anidjar, 2008: $84)$.

${ }^{23}$ Urvoy considers Hussein as one of the precursors of modern Muslim critical thought. In my view, Urvoy's remark about Taha Hussein's call to approach Arab cultural heritage, as a foreigner/outsider did not had the attention it deserved (cf. Urvoy 2006:607). As a matter of fact, Hussein's positivist reading of "pre-Islamic" poetry was a clear expression of a eurologo-centrism that considered western modernity as universal, and therefore should be emulated. Arab societies future was the West, not the orient. Hussein's reading Arab-Islamic cultural heritage as a stranger means in fact as a westerner does; a wordplay on: $\dot{g} a r i \bar{b}$ (stranger/foreigner/outsider) and $\dot{g} a r b \bar{\imath}$ westerner): Hussein's reading is, therefore, one-directional critique, whereas Khatibi's conception of the outsider/stranger is that of professional: a double critique reading that decolonises, de-sacralises, and de-centralises all essentialising/essentialised thought.

24 According to Gottfried Arnold (1666-1714): “L'orthodoxie ne peut pas être définie comme un dogme, mais résulte simplement de la situation privilégiée obtenue par des clercs en échange d'un soutien inconditionnel aux puissances politiques. Des lors on ne peut pas parler d'objectivation dogmatique d'un message religieux, d'un kérygme, mais seulement de l'organisation d'un système politique et clérical", (Orthodoxy can not be defined as a dogma, but simply as the result of the privileged position achieved by the clerics in exchange for unconditional support for the political powers. Thenceforth we cannot speak of any dogmatic objectification of the religious message, a kerygma, but of an organization of a political system and clerical only.), (Meslin, 1973: 31). This Passage is also quoted in Sylvain Jean Gabriel SANCHEZ L'historiographie du priscillianisme (1559-2012) http://sjgsanchez.free.fr/historiogsanchez.pdf, pp.6-7 
western scholarship: Islamic, epistemology, methodology and identity are essentialised by and through both Orientalism (for instance colonial discourse) and traditionalist islam, and later on through NeoOrientalism and a Political islam; both power discourses are policing this imagined borderline.

Failing to see beyond the curse of confessional and cultural affiliations, and their ethnicisation and politicisation, worthy of biblical genealogy ${ }^{25}$, and how double critique actually destabilises all sorts of affiliations and de-sacralises all religions, mythical origins, John Erickson finds it bewildering that four thinkers ${ }^{26}$, among whom Khatibi, are serving not only two masters as it were: Muslim (Sunnī) faith system and Western culture, literature and thought, but also serving two binary systems at the same time: a faith system versus a secular system!! As expected ${ }^{27}$ he painted a portrait of what Khatibi would call Sartre shedding tears ${ }^{28}$ :

${ }^{25}$ Ethnicisation and politicisation, in Western discourse, of the categories Muslim and Jew - which were primarily religious and theological categories began in the period of the enlightenment during the Catholic Reconquista and the expulsion of Jews and Muslims of the Iberian Peninsula. (Cf. Anidjar, 2003; 2008)

${ }^{26}$ The four postcolonial thinkers whose writings Erickson investigates are: Tahar ben Jelloun, Abdelkébir Khatibi (Morocco), Assia Djebar (Algeria), and Salman Rushdie (Indian subcontinent).

${ }^{27}$ The expression "as expected" is a deliberate invitation for trouble. It is une mise en crise of who-expects-what-from-whom? In anticipation, I was expecting Erickson to tell us exactly about his own pre-conceived expectation: these four Muslim thinkers were expected to be and behave as believers: How does a Muslim believer read in a Sisyphean manner his own system of faith through western lens (à la Prometheus)? It is the destiny of Khatibi - as expected - to be in this Sisyphean state: trapped in being a Muslim believer, but he should leave (as expected) the critical work to Orientalism. What Erickson fails to see is that Khatibi is, epistemologically, challenging this notion of expected-of him to be and act as a believer, this curse of affiliation (estrangement) through double critique in order to unmask it as power discourse. Double Critique is not a western theory. It is not an Islamic theory either. It does not need to be. It is simply a theory and praxis of the transtextual that is constantly and insistently de-constructing all master narratives.

${ }^{28}$ On this Khatibian allegory, see please my forthcoming translation of Khatibi's book: Vomito blanco: sionisme et la conscience malheureuse (Vomito Blanco: Zionism and the Unhappy Consciousness), specially the second chapter: "les larmes de Sartre » (Sartre's tears): "Même Sartre - de coutume un dialecticien unique - y perd la tête: le dialecticien s'improvise en taoïste, puisqu'il accepte les contraires au même temps, mais un mauvais taoïste, puisque cette contradiction interne á son system ne peut être proférée que dans un déchirement indépassable: c'est encore la conscience malheureuse qui fait Sartre verse ses larmes sans pouvoir les essuyer avec sa dialectique éblouie." (Even Sartre - usually a unique dialectician - loses his tongue in all this: a dialectician who acts now as taoist. He accepts two opposing positions at the same time. Sartre is, however, a bad taoist, since he is unable to utter this contradiction - internal part of its system - unless it comes out as an unsurpassable rift: it is the unhappy consciousness that once again causes Sartre to shed his tears without being able to wipe them with his dazzled dialectics); Khatibi, 1974: 20-21 
The writers I am about to study are, to varying degrees, believers in the Islamic (Sunnī) faith system, and draw willingly and strongly upon western culture, literature and thought. But in strikingly different ways, their writings refute or clash with certain of the strictures imposed in the name of Word, of the Qur'ān, the Sunna. (Erickson, 1998: 2)

Instead of negation - in Erickson's case mutual negation - through which essentialising discourses articulate cultural and identity difference, Khatibi proposes what Homi Bhabha calls negotiation/translation- not compromise $e^{29}$. The notion of negotiation " conveys a temporality that enables the post-colonial mind to articulate antagonistic or contradictory elements: a dialectics without the emergence of a teleological or transcendent History." (Bhabha, 2004: 37) At this juncture, the question is no longer whether the critical discourse, operating as double critique, should or should not re-iterate the discourses that it intends to examine, but rather it is a

\footnotetext{
${ }^{29}$ Compromise is what characterises every reformist paradigm. In Arabic the term used is tawfiq, an operative key concept that Arab critical thought have been deconstructing for ages now! In the classical period, several forms of reformist paradigm have seen the light: In law, al-Shafi' 1 's (d. 820) canonisation of $u s \underline{u}$ l al-fiqh (Sunnī Jurisprudence) was a form of compromise between rational-bound approach and tradition-bound approach. In theology, Abu al-Hasan al-Ash 'arī's (d. 936) canonisation of ușūl al-dīn (Sunnī Creed) was seen as a compromise between the Mu'tazila and ahl-Hadīt with regard to the issue of status od the Qur'ān (whether it was created [Mu'tazila ] or not-created [ahl-Hadīt ]). According to this paradigm, reform was seen as a religious duty on the one hand, and was articulated as a synthetic project of conflicting positions, literary systems (ideas, interpretations, ideologies etc.) on the other. The same happened in the great reform of Arabic language, which Bağdād school stood for: a compromise between Kūfa and Bașra schools. In modern reformist paradigm, the term-pair al- 'așāla wal-mu 'ạşra, the history of which shows clearly that the term 'așāla is paradoxical, both in terms of its use by opposing discourses, and in terms of its fossilised nature, similar to Arkoun calls the "dogmatic mind". The latter is an imagined impenetrable fortress that characterizes every fundamentalist-like thought. The issue of al-'așāla wal-mu 'ạsra has been dealt with differently, from different angles, in every Arab and Islamic society, and in different periods. Cf. Beleqziz, 2009) The problematic of al-'așāla wal-mu'ạsara in Arab/Islamic thought is exclusively Muslim or religious. It was the problematic to and from which all movements of thought had to relate: Muslims, Christians, and Jews. While Muslims and Christians have been investigated, Jewish role in Arab Nahda is still awaiting serious work. Cf. Behar's and Benite's outstanding work: Modern Middle Eastern Jewish Thought: Writings on Identity, Politics, and Culture 1983-1958. It shows how wanting are the current discourses on Nahda and Nahda agents. Let's hear from one of these agents, an early Jewish feminist and the founder of the organization nahdat al-nisa ' from Lebanon: “ My sisters, God will not change a people until they change themselves (a quote from the Qur'an, Q. 13:11), and this applies to us, the women of the East ... A woman - with all pride - is the essence of life and its joy, the poetry of beauty and perfection ...when we recite a poem by al-Ma'arri, al-Mutanabbi, or Abu Tammam al-Ta'i." (Behar and Benite, 2013: Chap.10). This passage is from Esther Azhari Moyal's (d. 1948) address at the American College for Girls in Beirut.
} 
question of form, meaning, and position that critical discourse bestows on them. Khatibi considers any call to reject the West an illusion for the simple reason that the West resides in "us" Arabs. The question of whether the West resides in "us", Arabs, or not becomes a question of how and what sort of west resides in "us" Arabs, and what sort of "us" arabs:

Know that the Arabs' problem - in its extreme form - we believe, is a west, whose difference is difficult to deal with...if the west is in us - not as an absolute entity [metaphysical idea], but as a difference that we are able to compare to another difference. Khatibi, 2000:30

When we change the vantage of point and remove any barriers that hinder the weaving movements ${ }^{30}$ of double critique, Erickson's split identity - a west versus an east - is replaced by a hybrid site. The west resides in the Arab-subject not as an absolute difference, but as a comparable difference: The Arab-subject is a bilingual being ${ }^{31}$.

Roussillon, a French sociologist of modern Arab societies, has tried, somehow, to penetrate unsuccessfully into the "fortress" of what Arkoun calls the "hermeneutical circle" inside which Khatibi resides, and upon its body he exercises his intimate gaze. Roussillon has proposed clôture réformiste (reformist enclosure) ${ }^{32}$ as a substitute notion to Arkoun's "hermeneutical circle". According to him reform in contemporary Islamic thought is a debate, rather than a doctrine ${ }^{33}$;

30 The expression "weaving movements" recalls the imagery of the movement of the embroidering needle and the bilingual hand that inter-laces poetry. (See note 17)

${ }^{31}$ Bilingualism is not necessarily two languages, but a concept that denotes the deconstruction of the One. Every language is diglossic, says Khatibi: the spoken and the written. An interpretative discussion of this concept in relation to Khatibi's concept of the orphan book can be found further down in of this paper.

${ }^{32}$ Unlike what the French term clôture (translated here as enclosure) denotes, Alain Roussillon suggests here " un quelconque $\langle<$ enfermement $>$ de pensées ou de curiosités. Le recours á cette catégorie $<<$ clôture $\gg>$ vise plutôt à saisir le principe de l'unité d'un débat, c'est-à-dire la façon dont, précisément, au-delà des divergences de posture, les différentes pensées en présence ont en commun de se situer par rapport à un certain nombre d'interrogations qui sont les même pour tous." (Whatever "confinement" of thoughts or curiosities. (Using this category "enclosure" aims rather at grasping the principle of unity of a debate. That is the manner according to which - beyond any divergences of position, the different lines of thought present have in common: namely to approach a certain number of interrogations that are identical to them all.) Roussillon, 2005:12.

${ }^{33}$ One of the salient aspects of "reform as doctrine" in western religious reformation was the de-sacralisation of the Roman Catholic perception of the sacredness of the Bible (muqaddas). According to the latter any access to the Holy Bible was forbidden for the non-clergy. Reform, in the protestant reformation, meant de-sacralising this catholic perception by making the Bible available in non-Latin vernaculars. In other words, what was desacralised by the protestant reformist was the Latin Bible canonised by the 
a debate for everyone to pitch in, irrespective of intellectual reference or affiliation. From the 19th century onwards, reform (ișlāh) has been debated within the term-pair al-'așâla wal-mu'āṣara (understood as either authenticity and modernity or authenticity or modernity). In the 19th century these two terms had a mimetic reflections: two geographical locations and two civilizational models: East and West respectively. In his reformist enclosure, Roussillon failed to find a place for frontierial thinkers that exercise critical liminality. "He failed to find", to put it mildly, is an expression of a methodological inability and epistemological myopia towards non-reformist paradigm. Khatibi - a professional outsider, is he a partaker of the reform debate? Is he its Judas? Or is he "Europe's francophone, who has undressed it"? ${ }^{34}$

Arkoun's "hermeneutical conflict", however, maps Islamic discourses and orientalist discourses in a triangular relation with and in opposition to scientific thought. In this triangular relation, the first two discourses are subjected to the scrutinising gaze of the critical mind: Where epistemology and ideology are "undressed" and made to stand naked. Arkoun confesses that ideology has often the upper hand in modern Arab-Islamic thought, even among some of the most vocal Arab intellectuals - as in the case of the Moroccan historian and philosopher Abdallah Laroui ${ }^{35}$ - due to the impact of the anti-colonial

only sacred church: heavenly Jerusalem. The History of the Bible in ArabIslamic Orient had a different story. The Bible has been translated into Aramaic, Syriac, Coptic... and Arabic - even before the Mohamed mission. The Qur'ān, however, has always been available to those who could read, even to non-Muslims: Jews and Christians. The metaphysics of the One: one God, One religion, one language common to monotheism is a mythic account of the issue of origin. The rich debate in classical islam, even in the Qur'ānic text - about the Qur'ān, its divine source, composition, versions, etc., is a clear witness to that effect. Nowadays, Muslim orthodoxy tries to prevent today's Muslims from having similar debates in public. The official Ulama use the argument that such debates would only lead to the perdition of the common people. In this regard see the interesting debate in post revolution Tunisia on "the Qur'ān between Revelation and Text" organised by TnMédias and which TV-channel broadcasted in August 2011. http://vb.tafsīr .net/tafsir27981/\#.VSZfDFy9uqw

One thing should retain whenever we discuss the issue of reform in the ArabIslamic context is that from a stage as these lexicographicalised terms: tajdì $d$, 'ișlăh, 'ijtihād, 'ihy $\bar{a}^{\prime}$ ', 'inbi 'a $\bar{a} \underline{t}\left(b a^{\prime} \underline{t}\right)$ indicate, reform has been internalized in the religious, the social, the political, cultural registers.

${ }^{34}$ The last question is inspired verbatim by Réda Bensmaïa's title of his chapter: "Exotopia or L'Europe mise à nu par ses francophones, même!" (Bensmaïa, 2010)

${ }^{35}$ Arkoun refers to Laroui's book L'Idéologie arabe contemporaine: essai critique, in which the term-pair al-'așāla wal-mu 'āṣra was re-visited. The context of the Israeli-Arab war in June 1967 and the catastrophic defeat of the Arab Armies had a traumatic effect (passim note 26) that not only shattered Arab nationalism's dreams, but also triggered a second awakening of what we call today: political islam and Salafism (in its combatant forms). This is the compromise (tawfiq) that Arkoun has been warning against: The triumph of both neo-orientalism and Muslim orthodoxy. See Khatibi's three articles that we are going to deal with in this paper: "L'orientalisme désoriente", “penser 
climate, in which the critical mind has given concessions to nationalism and religion. Similar concessions had been made earlier to nationalism and religious fundamentalism and led to the failure of Nahda project. Concessions were, in fact, the result of colonialism and anti-colonial sentiments together that derailed the second generation of Nahda from its initial course:

On the Muslim side, it should be noted, first of all, that if we neglect the alluring fundamentalist discourse that despite having a great mobilizing force, it is devoid of any scientific merit, the real animators of the debate are very few. ${ }^{36}$ (Arkoun, 1985:92)

I have noticed, after many years of teaching Islamic and Jewish studies $^{37}$, that contemporary Western and Muslim scholarship on Islamic Studies - Qur'ānic Studies, or Biblical Studies, hardly mention Khatibi and Benslama ${ }^{38}$, despite the fact that they have been prominent animators of critical debate about the need or " a new language of theoretical critique" that constantly seeks to overcome the given grounds of opposition and open up a space of translation: a place of hybridity,"(Bhabha, 2004:37) a kind of liminal site. Khatibi in le chercheur critique gives another definition ${ }^{39}$ of the qualifier critique - as part and parcel of the new language of theoretical critique:

First! Let's deal with this problem of vocabulary, the term 'critical', before going any further. As we know, there is in this notion, the idea of putting in crisis (mise en crise) - which is

autre" and "décoloniser la sociologie". Equally important is Khatibi's critique of Laroui's historicism which he describes as a theological artifice dressed in an ideological form." (Khatibi 2002 103)

${ }^{36}$ Arkoun, 1985: 92:"Du côté musulman, il convient de noter, en premier lieu, que si l'on néglige le discours fondamentaliste doué d'une grande force mobilisatrice, mais dénué de pertinence scientifique, les animateurs du débat sont en nombre très réduit."

${ }^{37}$ I remember vividly, since the event that I am relating here represents a turning point for many of my students, the first post-graduate class that I taught in Islamic Studies. The course was Islam in the $20^{\text {th }} \& 21^{\text {st }}$ centuries. Everybody was expecting a course on fundamentalism, terrorism, but to their surprise I proposed the following topic: Modern Critical Thought in ArabIslamic Studies. Some of the students suffered under what I have called here the curse of affiliations: Was Arkoun a Muslim? That is a believer? To them he was not! Unintentionally, they were re-iterating the same accusations that Muslim orthodoxy has been raising against the free thinkers. Most of them they have learned how to de-construct the theologically based conception of the term muslim and islam. Some of those students were Muslims who proved to be promising scholars. Two of them are contributors in this special issue.

${ }^{38}$ I would like to draw the reader's attention to two works of Benslama in particular: La psychanalyse à l'épreuve de l'islam. Paris: Flammarion translated into English by Robert Bononno, Psychoanalysis and the Challenge of Islam (2009), and la guerre des subjectivités en islam. Paris: Nouvelles Éditions Lignes.

${ }^{39}$ Passim note 18. 
often forgotten. Critique means putting both itself and the object under investigation in crisis at the same time. ${ }^{40}$ (Khatibi, 2002:319).

\section{Decolonising: thought-other}

Three of Khatibi's articles - written in the period between 1976 to 1981- are of special importance to us here, "L'orientalisme désorienté"41(1976) "décolonisation de la sociologie" (de-

40 " $D$ 'abord un problème de lexique, le mot <critique $>$ avant d'aller plus loin, il y'a en le sait. dans cette notion, l'idée souvent oubliée d'une mise en crise. La critique comme mise en crise á la fois d'elle même et de l'objet dont elle s'occupe...En ce sens aussi, la critique est double: critique de sa loi intrinsèque, et celle de la loi sociétale." Khatibi, A. Le chercheur critique, Chemins de traverse: essais de sociologie (Rabat: Université de Muhammad V - Souissi 2002) 319.

${ }^{41}$ Khatibi, A. L'orientalisme dérioenté, in Abdelkébir Khatibi, Chemins de traverse: essais de sociologie (Rabat: Université de Muhammad V -Souissi 2002) p.74. This text was published under the title "Jacques Berque ou la saveur orientalé" (Jacques Berque or the oriental Flavour), in Les Temps Modernes (Paris: June 1976). It was published under the current title in Maghreb Pluriel (Paris: Denoël) 1983:113-145. Khatibi warns his reader that his article on Berque does not imply directly that "Berque is a legitimate heir to the colonial ideology and to its sociologie musulmane under the protecting eye of the "saint" Collège de France." As a matter of fact, Berque is considered a "theoretician" of de-colonisation. Khatibi's analysis of Berque's discourse on Arabs shows how Berque has invented "his arabs", who comes "directly from metaphysics in the heideggerian sense of onto-theo-logy." (Khatibi 2002: 71) Unlike Said's work Orientalism, which is considered a seminal work in postcolonial studies, few people have actually paid attention to this work of Khatibi on French Orientalism in the Anglo-Saxon world of Academia. (Lionnet, 2011; Gronemann, 2009) Various reasons have been proposed as why such a universal thinker (theoretician, writer, philosopher, sociologist, poet, playwright, political activist, academician) have not been recognised! As we know all of Khatibi's works are authored in French. Apart from few works, almost all of his works have not been translated into English. On the issue of Maghrebin studies in French see Edward Burke III "Theorising the Histories of Colonialism and Nationalism in the Arab Maghreb" (Burke III, 2009: 17-34). Daniel Martin Varisco's omission of and silence about Khatibi's work from his list of critiques by Muslim and Arab scholars before Said's Orientalism is very surprising, to say the least. In a recent e-mail addressed to me, Varisco wrote: "Joshua, Oxford wanted a minimum of non-English references, unfortunately. Thus many valuable references had to be left out." It is even more surprising that someone like Hišām Șālih ignores the seminal work of Khatibi on French Orientalism in an edited work in Arabic on Orientalism (Arkoun, 2011) al-'istišrāa bayna du'ātihi wa mu 'âriḍīh (Orientalism between its proponents and opponents) which translates a number of articles of both proponents and opponents of Orientalism. He presents a narrative consisting of two moments which he calls: Anwar Abdel Malek's moment: "L'Orientalisme en crise" (Orientalism in Crisis), in Diogéne 1963), and Said's moment: Orientalism in 1978. One thing is sure is that Șālih tries to define that something else (see the note 31) that causes the orientalist discourse to become more defensive and apologetic under the attacks of these new native intellectuals. I am very glad to see the renewed interests that some postcolonial scholars in Khatibi's works: Mahmut Mutman recognises this postcolonial gesture (in English language) that took 
colonisation of sociology), and "pensée-autre (thought - other). The last two were published in 1981. In these seminal articles, Khatibi presents three critical concepts, constitutive of the theory of double critique, and operative in its critical language (bilingualism): orientalism, decolonisation and otherness. Prior to Edward Said's Orientalism (1978), Khatibi published in 1976 the article "L'orientalisme désoriente" (orientalism disorientates), and in which he dealt with French Orientalists: Louis Massignon (d. 1962) and Jacque Berque (d. 1995) and through their works he outlines three characteristics of (French) Orientalism on the one hand, and the aims of the orientalist discourse(s) or ideology at work ${ }^{42}$, on the other:

1. Orientalism deep-rootedness in the soil of metaphysics: islam and arabness, which, according to this approach, are defined as "a theological transcendence and a hypostasised history," and as "a high spirituality parallel to a passionate sensuality" respectively. (Khatibi, 2002: 72)

2. Non-contradiction between positivism and spiritualism: " a binding unity between essentialism, positivism and metaphysics. It is remarkable how Khatibi dissects the orientalist narrative on its proper history and the illusion of the unity of its enunciation on its object orient, arabs, islam. Using Heidegger's analysis of the Techniques as a prerequisite for understanding the position of Orientalism in social sciences, Khatibi unmasks the will to dominate immanent in the Orientalist discourse: "the destiny of the Technique is the same as the destiny of metaphysics, and science presents itself as a supreme simulacrum (will-to-will) of Western domination." (Khatibi, 2002:74) Orientalism in this vein continues its course, loyal to its metaphysical foundations, as if Nietzsche, Freud, Heidegger, Marx, Foucault, Derrida have never existed or spoken. (Ibid)

place two years before Khatibi's death in 2009: “As an alternative to Massignon, I follow Gayatri Spivak's advice and offer the Moroccan psychoanalyst and writer Abdelkébir Khatibi's fascinating reading of Muhammad's biography in his essay 'frontiers'."(Mutman, 2007:108. See also Mutmam, 2014. Being a trans-textual thinker who weaves in and out of various schools of thought is evident from the "testimonies of debt" that for instance Roland Barthes' and Jacques Derrida have "confessed" on paper: Barthes title "Ce que je dois à Khatibi" (What I owe to Khatibi) (Barthes, 1997:121-123), and Derrida's personal address: "Cher Abdelkébir, vois-tu je me considère ici comme le plus franco-maghrebin de nous deux, et peut être le seul franco maghrebin." (Dear Abdelkébir, I consider myself here as the most franco-maghrebian of us two, perhaps the only franco-maghrebian). (Derrida, 1996: 29)

${ }^{42}$ It should be borne in mind that the issue under scrutiny by "native" critical intellectual is not western scholars' erudition, or their ethno-confessional affiliations, but rather something-else. This something-else reveals the following truth: solidarity in opposition: orientalism and fundamentalism as two opposing essentialisms are in solidarity as far as both study-object (islam) and the division of tasks are concerned. 
3. Orientalism in its various discursive forms: Christian, Idealist or Rationalist, seems to be in" solidarity with humanism, in which theological humanism finds its shelter," after the scholastic god in the 19th century withdrew from the western scene, giving up his place to man as the subject of history." (Ibid) The logical conclusion that Khatibi draws from this withdrawal is that Orientalism "recovers this scholastic God with (fr. chez) the Arabs.” (Ibid), Orientalism's “arabs".

Mapping Orientalism's various discourses means according to Khatibi a kind of periodization that consists of two unequal moments within Orientalism itself. ${ }^{43}$ Transiting from one moment to another is marked by a break (fr. ébranlement):

1. Classical orientalism: stretching from the 12th century to the Second World War. This period-moment is marked by philology, historiography and culturalism (ethnography).

2. Post-World-War-II orientalism: This type of orientalism has become, according Khatibi, inserted within the field of social sciences. Although French Orientalism began to "open up for, inter alia, structural analysis, semiology and Marxism, the trial of this body of knowledge was done on the basis of Orientalism's metaphysical foundations." (Khatibi, 2002:73)

Khatibi attends attentively to the second period of Orientalism, specifically to French Orientalism, and, more precisely to this institutional Orientalism - College de France - represented in its two orientalists: Massignon and Berque. Two points about this institutional orientalist discourse about these two categories: islam and arabs should be retained here:

Massignon's eschatological discourse on islam, which he depicts as religion of faith, shall save the Abrahamic humanity after the failure of both Christianity and Judaism because "Christianity has deviated from the inaugural truth, and has forgotten its prophetic mission by

\footnotetext{
${ }^{43}$ Khatibi speaks of two periods, historically speaking, of Orientalism. This should not be conflated with any kind of typology or taxonomy of Orientalism, nor should we infer from Khatibi's periodization any kind of Manichean definition: "good"/"bad" Orientalism. Khatibi's choice of the 13th century as a point of departure finds its explanation in the fact that the first chairs of oriental languages began in the West in 1225 after the decision of council of Vienna. The term "orientalist", however, appeared at the end of the 18 th century. One finds an echo of this discussion about Western Islamic and Arabic Studies in an intra-orientalist discussion, to which Rodinson makes allusion, a kind of discourse on discourse. Rodinson's historicizing approach to the phenomenon of orientalism - dialectic of historical reality and thought renders him a proponent of a discourse on methodology against other discourses within orientalism. Rodinson Marxist theory on orientalism has contributed to a taxonomy - hierarchized typology) of various orientalists discourses. (Rodinson, 1974)
} 
covering over the colonialist crime. Judaism has been misled by Zionism." (Khatibi, 2002:74). Khatibi concludes that "Massignon's Abrahamic Allāh maintains the speech of the humble and the dominated," (Ibid) and for that reason, Massignon proposes "his grand reconciliation of the three religions" (Ibid).

The task of double critique transcends all sorts of essentialising polemics and engage through critical language - and as such it is always bilingual ${ }^{44}$ - an act of de-colonisation / re-appropriationwhich should not be mistaken for negation (as I have mentioned earlier), or a revival of a repressed authenticity; a lost book, but rather as an act of negotiation which consists of:

1. "A deconstruction of logo-centrism and ethnocentrism. That is "a need to ponder on the structural solidarity between imperialism in all its forms and the expansion of social sciences." (Ibid)

2. "A necessary critique of knowledge and discourses that various societies of the Arab world have elaborated on themselves." (Ibid)

Exercising double critique relentlessly means a) unveiling the impact of producing a body of knowledge on the world (Orient) by social sciences that is conceived and developed in the West at the very moment the latter is exercising its imperialist hegemony on the world through the expansion of industry, and b) unmasking the sites wherein contemporary Arab knowledge "need to radically break with its theological and theocratic foundations that mark the ideology of islam and of all monotheisms." (Ibid). The task at hand is "to localise the sites where a such knowledge is an ideological adaptation of metaphysical concepts." (Ibid)! Remarkably, Khatibi does not exempt

\footnotetext{
${ }^{44}$ Khatibi asks this pertinent question vis-à-vis the dichotomy West/East, and which defines his notion of bilingual identity: "Shall we reject Europe and distance ourselves from it for good? Wouldn't that be an illusion, for the simple reason that Europe resides in us? Know that the Arab's problem - in its extreme form - we believe, is a west, whose difference is difficult to deal with ... if the west is in us- not as an absolute entity [metaphysical idea], but as a difference that we are able to compare to another difference." (Khatibi 2000: 30. In his second auto-biography, Khatibi speaks of the 'self' as a mask of 'alterity': "On the way to ourselves [us], we may say: I or: me, I, if one is in the state of listening to one's subconscious. The self is neither hateful nor adorable. It is a unique mask of alterity" (Khatibi, 2008:8). Khatibi uses also the term of bilingualism to describe the dynamic character of identity. In postcolonial theory, similar concepts have been proposed for the non-essentialist view of identity such as hybridity (Bhabha), mapping (Deleuze \& Guattari), mestizaje [crossbreeding] (Anazaldua), interstitially and hyphenation (Misha), critical identities (Král). Today, it is difficult to "apprehend identity independently of identity construction and the mechanisms it involves" (Král, 2009: 2).
} 
Arab Marxist ${ }^{45}$ sociology from playing, as it were, this game of ideological adaptation. Where does this radically breaking leave contemporary Arab knowledge then? Does it necessarily mean that it ceases to be being Arab-Islamic? Or does it mean that once it breaks away (from whatever and wherever it is imagined to be belonging to) it becomes Western ${ }^{46}$ ? No! It simply means that the structure of contemporary Arab thought experiences " a conflictual interference of two different types of episteme: The Western episteme covers the other." Furthermore, and in order to understand fully the position that contemporary Arab-Islamic thought is in a state of subordination to the Western thought - Khatibi goes beyond what traditionally is articulated in the dichotomy of a 'West' versus an 'Orient'. Double critique entails opposing to Western episteme its unthought of/ its outside (fr. dehors) while radicalising the margin, "not only in thought in Arabic, but in thought-other which speaks in languages, and listening to all thoughts irrespective from where they comes from," (Ibid) Matrūz Thought.

In light of what Khatibi calls pensée-autre (thought - other) that speaks and listen to all thoughts, double critique breaks away from all sorts of foundationalist discourses: Salafi, Liberal, classical Marxism, reformist etc. since they are still trapped within or moulded by the theological and theocratic foundations on the one hand, and the ideological adaptation of metaphysical concepts on the other.

\section{Freud and the question of origin}

Asking the question about the origin of islam does not escape a historiography of the vantage point and how this origin is imagined. Needless to go through all the polemics around this imagined origin, but instead we would like to be a bit more attentive to how this question of origin being re-casted by Khatibi. Re-casted means, here, how Khatibi re-iterates the question of origin through a dialogue with Freud's psychoanalytical enunciation, which Benslama describes as "an incident remark." (Benslama, 2002:117):

\footnotetext{
45 "C'est pourqoui cette pensée-autre dont nous réclamons n'est ni marxiste dans le sens strict, ni antimarxiste dans le sens droitier de ce terme, mais aux limites de ses possibilités. Car nous voulons décentrer en nous le savoir occidental, nous dé-centrer par rapport à ce centre." (This is why this thoughtother which we claim is neither Marxist in the narrow sense, nor anti-Marxist in the right-wing sense of the term, but the limits of its possibilities. It is because we want to de-centre in us the Western knowledge, and de-centre ourselves in relation to this centre" (Khatibi 2002 117).

${ }^{46}$ Laroui in his conclusion, which is in my view, could be interpreted as is in line with the very essence of what double critique does - applies to refusing Arab Culture as well: "The refusal of Western culture does not in itself constitute a culture, and the delirious roaming around the lost self shall never stir it up from dust" (Laroui, 1967).
} 
I regretfully have to admit that I cannot give more than one sample that I have not the expert knowledge necessary to complete the investigation. This limited knowledge will allow me perhaps to add that the founding of the Muhammadan religion seems to me to be an abbreviated repetition (abgekürzte Wiederholung) of the Jewish one, in imitation (Nachahmung) of which it made its appearance. There is reason to believe that the Prophet originally intended to accept the Jewish religion in full for himself and his people. The regaining (wiedergewinnung) of the one great primeval Father (urvater) produced in the Arabs an extraordinary advance in self confidence which led them to great worldly success, but which, it is true, exhausted itself in these. Allah proved himself to be much more grateful to his chosen people than Jahve had in his time. The inner development of the new religion, however, soon came to a standstill, perhaps because it lacked the profundity, which in Jewish religion resulted from the murder of its founder. (Freud, 1939: 148-149)

Khatibi's reading of this passage takes different focal positions in an untiring bi-directional movement: reading of Freud, Derrida, Muhammad's biography, and Islamic tradition. His aim is to "carry on from where Freud left off in the analysis of monotheism" - not in the sense of an ideological adaptation of metaphysical concepts. He crosses, however, the border and back again. He keeps doing this all the time, several times. It is his profession. He puts into question (mise en crise) a theory - his own - to deconstruct the orientalist discourse latent in Freud's enunciation, and in doing so, double critique re-appropriates - neither mimesis nor repetition of - Freud's theory of religion and its critical language: its limitations and silence in Freud's psychoanalysis on islam or in the words of Khatibi "islam is an empty space in the theory of psychoanalysis."(Khatibi, 2009: 689-696)

Fethi Benslama ${ }^{47}$, a lacanian psychoanalyst, takes also this short Freudian passage - the only passage ${ }^{48}$ - on islam or rather the issues of

\footnotetext{
47 Fethi Benslama is a Franco-Tunisian psychoanalyst and an engaged intellectual. Together with Khatibi, they led a research programme: "raison and un-reason in Islam" un programme de recherche intitulé « Raison et déraison en islam ».

${ }^{48}$ Worth mentioning, the Freud mentions the Arabs in another passage Moses and Monotheism. on the origin of the israelite Jewish god Jahve he quotes Eduard Meyer Die Israeliten und ihre Nachbarstämme: Alttestamentliche Untersuchungen (Halle: Verlag von Max Niemeyer 1906) pp. 60-71, saying: "The second fact, proved by E. Meyer, is that these Jews on their return from Egypt united with tribes nearly related to them, in the country bordering on Palestine, the Sinai peninsula and Arabia, and that there, in a fertile spot called Qades, they accepted under the influence of the Arabian Midianites a new religion, the worship of the volcano God Jahve." Moses and Monotheism, p. 98. Cf. Meyer E. Die Israeliten und ihre Nachbarstämme:
} 
origin of islam and in islam, especially its constitutive text the Qur'ān, and the fiction of Abraham/Ishmael genealogy; the figure of the father in Biblical and Qur'ānic archives ${ }^{49}$. Both Khatibi and Benslama recognise, as I do, the temporality of Freud's theory - as it is enunciated under the subheading of difficulties. It is not a declaration of non-jurisdiction, but of a reading of his days' orientalist imagined islam as an imitation of Judaism ${ }^{50}$ - which we today see its limitations - and a displacement of that body of knowledge: a new theory of religion with regard to the central position of the urvater and its appropriation and translation in islam. Khatibi accepts, as it were, Freud's text of islam as an invitation - from a professional outsider to another, of scrutiny of the pre-second world war's Western body of knowledge on islam and the Orient. Now let us see how Khatibi rereads himself, his own exile, and displacement into Freud's. Both of them are professional outsiders. ${ }^{51}$ Speaking of Freud, Khatibi reads him as thought-other:

Freud then transforms this margin, this frontier, into a working laboratory. With this move, this professional outsider displaced the notion of an anthropological ground upon which individuals and their properties, peoples and their memory are inscribed. He displaced thought in displacing himself - this, in fact, is the task of the professional outsider. A professional outsider, separated from his mythical origin. Precisely like Moses. (Khatibi, 2009:689)

Alttestamentliche Untersuchungen (Halle: Verlag von Max Niemeyer 1906) pp. 60-71.

49 Beslama F. La Psychanalyse à l'épreuve de 1'Islam (Paris: Flammarion 2002).

50 The term of day in those days - still in polemical literature - borrowing. Two hypotheses were advanced in orientalist discourse: the Jewish and/or the Christian origin of Islam. According Benslama "Freud quote was based on precise information gleaned from non-cited references." On Jewish and Christian origin of Islam see for instance Abraham Geiger, Was hat Muhammad aus dem Judenthume Aufgenommen? (Bonn: Gedruckt auf Kosten des Verfassers bei F. Baaden 1833); and Richard Bell, Origin of Islam in Its Christian Environment (Edinburgh: The Gunning Lectures Edinburgh University, 1925). The conclusion of these origin-fixed enunciations is that Islam has no proper origin.

${ }^{51}$ In his second autobiography Le Scribe et son Ombre ("The Scribe and his Shadow"), Khatibi describes this notion of "the professional outsider" in this way: "It happens that I introduce myself as Moroccan and as professional stranger ....as the character of my last work said:

'...He is a professional outsider', he said

'Funny trade!'

'It is not a trade. It is a mobile position in the world. One is able to cross borders: between languages, civilisations and markets. One day, one stops to meditate.

'You are still there, Amigo! She said

'Yes, Yes, always! When they look for me, they'll find on the road, the hand on my heart. "' (Khatibi, 2008:15) 
Now, how does Khatibi proceed? How in his exile - critical thought is always exilic - separates himself from his mythical origin ${ }^{52}$. Muhammad - the prophet of islam in Islamic tradition - is "the orphan ${ }^{53}$ of the book and the one who was not killed by his fellows and enemies". Beyond the various accounts codified in Islamic tradition about Muhammad's biography: birth, childhood, maturity, before and after Revelation, Khatibi distinguishes between Muhammad of the "family romance" and Muhammad - the prophet - the orphan of the book. Muhammad in "family romance": childhood is characterized, in Freudian terms, by substitution and duplication. Muhammad's lost father - Abdullah - is substituted by his grandfather - 'Abdul Muțalib - and Halima (wet nurse) is his mother's - Amina - duplicate, whereas Muhammad the prophet whose prophecy is "of orphanage of the lost book ${ }^{54}$ through which the prophet sacrifices his signature."(Ibid.691)

Interestingly, Revelation and its modi, as reported by Muhammad's biographers are read as "Ordeal of the Book and its script." Revelation's modi and states: "dreaming", "while awake", and "form and figure of an apparition" - that of the Angel that "speaks." The order of the Angel to Muhammad to 'iqra' is understood according Khatibi as recite. ${ }^{55}$, that is "read[ing the message] without understanding it." It is a di-phonic self-recitation: "reciting to himself through two separate voices that unite to convey the same message". In a symmetrical and circular logic, Allāh as addressor is the "other voice of Muhammad", whereas the "initial addressee is the prophet." What does it mean reciting/reading without understanding here? I would say, the question intentionally, goes beyond, without ignoring its polemical and erudite history and implications, the issue of Muhammad "family romance", and whether he knew how to read and write. It reformulates the question in terms of legibility and illegibility of the message. Muhammad in this circular logic "occupies sometimes one place, sometimes another." The prophetic message is illegible to him, since he inhabits it, but it is legible to his wife Hadīja:

From the modesty of Gabriel to the reassuring gentleness of Khadija, the word took body. The wife deciphered certain signs

\footnotetext{
${ }^{52}$ Cf. Derrida, J. Abraham, l'autre, in Le dernier des Juifs, (Paris: Galilée 2014) pp.69-126.

${ }^{53}$ Islam is an orphan religion in comparison with Freud's description in Moses and Monotheism: "The Mosaic religion has been a father religion, and Christianity religion became a Son religion." p. 141.

54 The lost book that Khatibi refers to is to Freud's "secret book", which he mentioned in his correspondence with Arnold Zweig in 1939: "I am waiting for nothing other than Moses who has yet to appear as sure as night follows day, after which I shall no longer need to be interested in any book of mine until my next rebirth" (Khatibi, 2009:690). Khatibi's notion of the lost book goes beyond the Bible of Freud. Cf. Derrida, 1995

${ }^{55}$ Q. 96:1. The verb 'iqra' in imperative, translated here as recite!, has been a focal point for several interpretations.
} 
of prophecy on her own body and on that of her husband. She read, in a way, on the imaginary body of Islām where, illegible to Mohammad himself, the prophetic message becomes apprehensible by the feminine body. (Burcu Yalim, 1988) ${ }^{56}$

This is what Khatibi calls identification and separation. Muhammad the prophet "identifies himself with the message and the Book ${ }^{57}$ that was written by No-one." Separation, however, is "between the legible and the illegible, the voice and the writing, the visible and the invisible, between the white signature [that of Allāh] and the sacrifice of the name [that of Muhammad], the survival and the transfiguration of the name." The very notion of Revelation/revelation (wahy) becomes in Khatibi's reading a gesture of trespassing he impossible! Desacralizing the notion of Revelation that Khatibi undertakes here brings to the fore what Arkoun, in his diagnosis of the sacralising reading of the Qur'ān, the thing that has been kept out of sight. That is "the impossible-to-think-of " since the 11th century: the notion of Revelation. (Arkoun, 2001:12) It is in this vein, that Khatibi calls upon Freud's gesture of desacralisation ${ }^{58}$ to undertake his own desacralizing of this impossible-to-think-of; "destabilisation of all notions of religion, of monotheism and of the Book." (Khatibi, 2009:690) Revelation in the case of Muhammad the prophet becomes in his insertion in "a symbolic genealogy much richer than that of the

${ }^{56}$ Cited in Khatibi, 2009: 692

57 On the notion of the book/Book: kitāb/al-kitāb in what traditionally is called western and Muslim Qur'ānic scholarship see (Madigan 2001). Interestingly, Madigan's erudite presentation of the scholarly debate oscillates between modern western scholars and classical Muslim scholars. While maintaining both scholarships separate, Madigan re-iterates - mimically - the orientalist discourse on Islam as a modernist discourse on pre-modern object. The modern Muslim scholarship on Qur'ānic studies is "enunciated as nonexistent". There is a huge epistemological and ideological difference between not mentioned and enunciated as non-existent. Nevertheless, Madigan's discussion of the notion of kitāb/al-kitāb, particularly Bell's differentiation between the Qur'ānas document and the Qur'ān as a source is interesting. Regarding contemporary Arab-Islamic scholarship on the Qur'ān see for instance Nasr Abu Zayd, mafhūm al-nașs (the meaning of the text), Muḥammad Arkoun: al-qur'ān: min al-tafsìr al-mawrūt 'ilā taḥlīl al-hițāb al$\operatorname{din} \bar{l}$ ( The Qur'an: from the inherited exegesis to the analysis of the religious discourse), Tayyeb Tizini al-nașs al-qur'ān̄ 'amām 'škāliyat al-binya walqirā'a ( the Qur'ānic text :the problematic of structure and reading), Ābed alĞābrī's four books: 1. an introduction: madhl ilā al-qur'ān al-karìm ( an introduction to the noble Qur'ān), 2. a tafsīr trilogy: fahm al-qur'ān al-hakìm: al-tafsìr al-wädih hasab tartīb al-nuzūl (comprehending the wise Qur'ān: the clear commentary according to the order of revelation), Khatibi "sexualité selon le coran" ("sexuality according the Qur'ān"). This is not an exhaustive list, but few titles of a serious scholarship in the debate about the Qur'ānic text.

58 Khatibi (2009:690) through the other demoralising gesture - an act of rationalisation, duplicates Freud' enunciative I/he: "But instead of reconciling himself with his god, like the Oedipus of Sophocles, he destroys all divine illusions, all religious illusions, and treats them as a symptom of neurosis." (Khatibi, 2009:690) 
family romance." (Ibid. 691) Reading this separation, these two genealogies, Muhammad "reveals himself to himself, and to his relatives as the new new testament." Khatibi construes revelation prophetic message - as socially radical. Revealing himself to himself and to his relatives Muhammad fought, adds Khatibi, against three figures: the seer (kāhin), the possessed (majnūn), and the poet $\left(\check{s}^{\prime}{ }^{\prime} i r\right)^{59}$. This three figures in Q 52:30 - as in the Qur'an's re-iteration of the accusation that Muhammad's opponents - become social actants in this double gestures of revelation against whom the prophetic message is radical:

The first belongs to a pagan genealogy and to its magic; the second, to its haunted margin and the third, to the act of tribal imagination. Mohammad destroys the pre-Islamic statues in order to appear to the world as the messenger (Rassoul) of 'the One-Only'. (Khatibi, 2009: 691)

How this business of Muhammad being the orphan of the book should be taken? First Khatibi re-visits the concept of the palimpsest. Here Khatibi offers us two different relational mudi of texts: the palimpsestuous $^{60}$ and the translational. It is a site - a frontier -

${ }^{59}$ Q. 52:30-31: "Therefore, continue to remind, for by the grace of your Lord, you are not a soothsayer, or madman, or do they say: A poet, we wait for him the evil of the time." (Shakir's translation), See also Q. 68:2; 81:22; 69:41-42. With regard to magicians and poets as antithesis to divine miracle and revelation see Q. 26.

Benslama refers to the repudiated Hagar, mother of Ishmael as the first person to call the god who spoke to her and named the yet to be born child yišma ${ }^{`} \bar{e} l$ (Ishmael), now her god, as god-seeing-me ( heb. 'él ro ' $\bar{l}$ ). By the same token she became the one who saw god as he saw her, even the well was called be'ér lahay ro' $\bar{\imath}$ (the well of the living one who sees me)(Gen. 16:11-14). Benslama mentions also that Spinoza considered Hagar a prophet. We should bear in mind that Hagar is not mentioned in Qur'ānic archive. As for the biblical figure, the Midianite Jethro, one his three biblical names, a name of his profession as a priest (Ex.3:1, kohēn midyān): Ex. 2:18, re 'u' 'èl (friend of god). In the Semitic "family romance", the one that Freud uses, and which both Khatibi and Beslaman make reference to, the god (jahve) that the Israelite "borrowed" from the Midianites (Ishmaelites/Arabs).

On this very important point, Arkoun asks the following question: "Why does the issue of the attitude of the associationists (mušrikün) vis-à-vis the phenomenon of revelation (wahy) constitute one of the strategic domains that needs to be studied if the intention be founding a new and creative thought concerning the significance of religions and its meaning? Using the historical approach shall typify the query as an anthropological question vis-à-vis the emergence of the religious language and its function" (Arkoun 2001:93). Arkoun and Khatibi, as well as Benslama, were aware of the limitations of the historical investigation. Reducing the issue to historical-textual criticism alone - that is to description of the events, names, identities, literary sources, origins of ideas and their genealogy - will simply not do.

${ }^{60}$ On this term and history and various applications in Genette's poetics see Gerald Prince's "Foreword" to the English translation of Gérard Genette book: Palimpsest: Literature in the Second Degree (Lincoln: University of Nebraska Press 1997), pp. IX-XI. 
"between different messages of monotheism". ${ }^{61}$ The One - unicity of Allāh and Arabic language - designates what Khatibi calls the "founding signature" 62 of the orphan book "in the Islamic imaginary. ${ }^{63}$ " In this frontier, a kind of pentecostal-like event takes place. This time, however, it is god who "changes language, the parabolic and the allegorical code," 64 in a hierarchy that stratifies the possible and the impossible. The possible: the game of palimpsest that presupposes "a book and its duplications, a testament which would be the origin with its copies." ${ }^{65}$ Khatibi does not deny its existence, but allocates to it a status and a set of functions: the oral, the written and symbolic levels - the inside. It is limited by the translational - transcross-frontierial - "where the lost book is precisely of the impossible origin. ${ }^{66}$ "It is the outside. Between the inside and the outside lies the question of borrowing. The origin, says Khatibi becomes the "mythical account of borrowings." 67

In Jewish, Christian and Muslim narratives of abrogation actually it is called the doctrine of abrogation - abrogation is postulated as retrospectively external, and circular-internally. It is a matter of law, continuity and discontinuity (negation). Khatibi calls this phenomenon cross-repression: Old Testament, New Testament, and Qur'an. In order to deconstruct this narrative of election of the "saved community", Khatibi through double critique, de-sacralises the mythical account of borrowing by depositing the following hypothesis: The lost book of monotheism is the split book: a Book without origin. Khatibi let Freud do the work first, and he carries on from where Freud stops. It is like writing with two hands. This is done through "a systematic reading of desacralisation". When Khatibi says that Freud de-sacralises, he means that he rationalises. What does Freud's decentralising/rationalising consist of? It is when Freud divides the One into two or multiple ones. For instance Freud deposits a narrative with three duplicates:

1. Moses the Egyptian is killed in order for the mythical founder to emerge.

2. Christ who "would in fact be a murderer who disguised himself in the angelic costume of a Redeemer, of a false victim."68

3. Muhammadan religion the foundation of which "seems to be an abbreviated repetition of the Jewish one, in imitation of which it made its appearance."

\footnotetext{
${ }^{61}$ Khatibi, 2009:692.

${ }^{62}$ Khatibi, ibid.

${ }^{63}$ Khatibi, ibid.

${ }^{64}$ Khatibi ibid.

${ }^{65}$ Khatibi ibid.

${ }^{66}$ Khatibi ibid.

${ }^{67}$ Khatibi ibid.

${ }^{68}$ Khatibi ibid
} 
Regarding the third duplicate, Khatibi seems to be at work again. Why an abbreviated repetition? Khatibi's measured answer is an expression of a calculated gesture that restrains from falling into narcissism of the victim - back to the curse of affiliations whether religious or nationalistic. An imitation? Yes, but one that "lacks the murder of the father, whose postulates is crucial to Freudian analysis". Benslama sees in Freud's "incident remark" an attempt to rethink origin and "a plurality of emergences and a resurgence of the same trace across time." (Benslama, 2002:117)

Khatibi's hypothesis of Muhammad as the orphan book of monotheism draws Muhammad's "family romance" in which he is an orphan, and on prophecy according to which Muhammad sacrifices his signature. He has a book of his own. He is the Book: He recites himself to himself. Allāh has no signature; or rather his signature is white with no trace. Muhammad was not killed by his people, or was he? Should he be killed in order for his mythical duplicate to arise, as was the case with Moses the Egyptian ${ }^{69}$ ? He sacrificed his signature, his book.

As to the Freudian concepts of repetition, abbreviated repetition, and imitation Benslama offers other explanations. Since repetition is "neither reproduction nor rumination," what is it then? He presents two definitions / registers of this psychoanalytical phenomenon:

1. On the symbolic level: the principle of language use dictates the same signs. In the case that the same produces new meanings, then one can conclude that repetition produces difference.

2. On the level of what is impossible to symbolise: In the case for instance of traumatism, repetition serves as tool with which one controls trauma. "It is in this case a vain attempt to come in terms with the return of the same." (Benslama, 2002:116)

3. On the term imitation, Benslama recognises the fact Freud used it in conformity with the orientalist thesis about the Jewish origin of islam. The idea of imitation denotes in the orientalist archive, an unlawful takeover and a mimicry that hides fraud, whence the palimpsestuous concept of an origin and a copy. In the Qur'ān's polemical discourse, returning Abraham is an act of Islām's refounding its self as the true monotheism linking its origin with the sealing end.

One should also consider the significance of Freud's portrayal of Arabs 'double role (being a lender and a borrower): the Arabs lent their god Jahve to the Israelites at the time of Moses and being a borrower at the time of Muhammad. In this cycle of borrowing and

\footnotetext{
${ }^{69}$ Derrida discusses the issue of whether Moses was threatened to be killed or was actually killed in the wilderness according to Bible and Midrash archives: Numbers 14:10. (Derrida, 1995:43-44). In Islamic biographies of Muhammad, several attempts to kill Muhammad were made by his people.
} 
lending, one cannot speak of an origin, but of multiple emergences and resurgence of the same trace across time; in other words, origins.

In conclusion, Khatibi's reading of Freud's passage as a an exilic text on islam being "an abbreviated repetition" shows intimately how double critique re-creates its critical language by exposing it to an inside and an outside reading in a weaving movement. Does Khatibi try to psychoanalyse islam or islamicise psychoanalysis? A legitimate question I would say? A question that perhaps only border police would ask:

For precisely these reasons, it is not, as I understand it, a question of psychoanalysing islam, nor of islamicising psychoanalysis, even less of judaising or hinduising it, but of exercising it as frontierial position in the language and exercise of a profession. (Khatibi, 2009:696)

\section{Conclusion}

In this paper/essay, I have shown how a double critic thinks, works, and navigates through theories, bodies of knowledge in reflexive manner. Double critical thought enjoys an unprecedented openness. It gets its force from scientific rationally that is in action in a world of conflict and contradictions, challenging different strategic, economic, political, ideological, and cultural models.

Khatibi's double critique paradigm is a theory of theory (metatheory) and a bi-directional exercise; a theory of de-centering centres and an exercise of de-centering the self as centre. A general theory, as we have seen, concerning how Khatibi for instance postulates the issue of origin an epistemological question and as discourse of difference, of transtextuality and transition. The issue of origin, all origins are narratives as mythical accounts of borrowing, upon which double critique builds its own narrative of fictionality, archive and memory. For example De-centering the Qur'ānic accounts of the origin is first of all a de-sacralisation of any reading as centre reading, including its own.

\section{Author biography}

Dr. Joshua Sabih (dr.theol) is associate professor in Middle Eastern \& North African Studies, and coordinator for Hebrew, Jewish and Israel Studies. Joshua Sabih's teaching and research include Arabic linguistics and literature, Quranic Studies, Islamic Law, Philosophy and Theology, Jewish, Karaite and Samaritan Studies, Jewish-Muslim Relations, Modern Arab and Jewish Thought, and Semitic Philology. Among his publications: Sabih, J \& El-Jaichi, S, (2015) I Averroes 
Fodspor: Samtalen mellem Religion og Filosofi, Copenhagen; "Isa Narrative in the Quran: The Making of a Prophet in 'Is This Not the Carpenter?': The Question of the Historicity og the Figure of Jesus. Thompson, T. L. \& Verenna, T. S. (red.). Sheffield: Equinox Publishing Ltd, SW 11, Kap. 12, s. 217-232 16 s. (Copenhagen International Seminar; Nr. 6, Vol. 1), Japheth ben Ali's Book of Jeremiah: A Critical Edition and Linguistic Analysis of the JudaeoArabic Translation, 2009 London.

\section{References}

Abu Zayd, N. H., 2014: Al-Tafkīr fì zaman al-takfir, al-markaz altaqāfī al-'arabī, Casablanca-Beirut.

Anidjar, G., 2008: Semites: Race, Religion, Literature, Stanford University Press, Stanford.

Anidjar, G., 2003: The Jew, The Arab: A History of the Enemy, Stanford University Press, Stanford.

Arkoun, M., 2001: al-qur'ān: min al-tafsīr al-mawrūt 'ilā taḥlīl alhiṭāb al-dīnī. (H. Saleh, Trans.), Dār al-țalī‘a, Beirut.

Arkoun, M., 1970: "Comment lire le Coran". In Le Coran, trans. Kasimirski, GF Flammarion, Paris, pp. 14-36.

Arkoun, M., 1985: Discours Islamiques., discours Orientalistes et pensee scientifique in: (eds.) B. Lewis, E. Leites, \& M. Case, As Others See Us: Mutual Perceptions, East and West, International Society for the Comparative Study of Civilisations, New York, pp. 90-110.

Barthes, R., 1997: "Ce que je dois à Khatibi" in: (ed.) A. Khatibi, L'Oeuvre de Abdelkébir Khatibi: préliminaire, Éditions Marsam, Rabat, pp. 121-123.

Belqziz, A., 2009: mia al-nahụa ilā al-ḥadātah. Markaz Dirāsāt alwaḥdah al-'arabiyyah, Beirut.

Benslama, F., 2014: La guerre des subjectivités en Islām, Nouvelles Éditions Lignes, Paris.

Benslama, F., 2002: La psychanalyse à l'épreuve de l'Istām, Falmmarion, Paris. 
Bensmaïa, R., 2010: Exotopia or l'europe mise à nu pas ses francophones, même! (eds) A. De Toro, K. Zekri, R. Bensmaïa, \& H. Gafaït, Repenser le Maghreb et l'Europe, Paris.

Bergo, B., Zagury-Orly, R., \& Cohen, J. (eds), 2007: Judeities. Questions to Jacques Derrida. trans. B. Bergo \& M. Smith, Frodham University Press, New York.

Bhabha, H., 2004: The Location of Culture, Routledge, New York.

Bloom, H., 1973: The Anxiety of Influence, Oxford University Press, Oxford.

Bonn, C., 1999, Mai 7: Articles et texts courts d'Abdelkébir Kahtibi. From www.limag.refer.org: http://www.limag.refer.org/Volumes/ArticlesKhatibi.PDF

Burke III, E., 2009: "Theorising the Histories of Colonialism and Nationalism in the Arab Maghreb" in: (ed.) A. A. Ahmida, Beyond Colonialism and Nationalism in the maghreb: History, Culture, and Politics, Palgrave Macmillan, New York, pp. 17-34.

Derrida, Jacques, \& Prenowitz, E., 1995: "Archive Fever: A Freudian Impression" in: Diacritics , 25 (2), pp. 9-63.

Derrida, J., 2014: "Abraham, l'autre" in: (ed.) J. Derrida, Le dernier de Juifs, Galilée, Paris, pp. 69-126.

Derrida, J., 1996: Le monolinguisme de l'autre , Éditions de Galilé, Paris.

Erickson, J., 1998: Islām and Postcolonial Narrative, Cambrudge University Press, Cambridge.

Freud, S., 1967: Moses and Monotheism,. trans. K. Jones, Vantage, New york.

Genette, G., 1982: Palimpsets: La litterature au second degré, Éditions du Seuil, Paris.

Hussein, T., 1926: fì al-ši 'r al-jāhilī , Dār al-Ma ārif lil-ṭibā'ah walnašr, Cairo.

Kahtibi, A., 1974: Vomito blanco: sionisme et la conscience malheureuse, Union Génerale D’Éditions 10/18, Paris. 
Khatibi, A., 2000: al-naqd al-muzdawij. Rabat: Manšūrāt Ukāẓ, Rabat.

Khatibi, A. 2009: December: "Frontiers: Between Psychoanalys," Third Text , 23 (6), pp. 689-696.

Khatibi, A., 2002: "La sexualité selon le coran" in: (ed.) A. Khatibi, Chemins de traverse: essais de sociologie, Université de Muhammad V-Souissi, Rabat, pp. 237-257

Khatibi, A., 2002: "L’orientalisme dérioenté" in: (ed.) A. Khatibi, Chemins de traverse: essais de sociologie, Université de Muḥammad V-Souissi, Rabat, pp. 69-90.

Khatibi, A., 2002: "Le chercheur critique" in: (ed.) A. Khatibi, Chemins de traverse: essais de sociologie, Université de Muḥammad V-Souissi, Rabat, pp. 319-324.

Khatibi, A., 2008: Le Scribe et son ombre, Éditions de la différence, Paris.

Král, F., 2009: Critical Identities in Contemporary Anglophone Diasporic Literature, Palgrave Macmillan, Basingstoke.

Laroui, A., 1967: L'Idéologie arabe contemporaine: essai critique, François Maspero, Paris.

Le Goff, J., 1993: Intellectuals in the Middle Ages, trans. T. L. Fagan, Blackwell Cambridge -Mass.

Madigan, A. P., 2001: The Quran's Self-Image, Writing and Authority in Islām's Scripture, Princeton University Press, Princeton.

Meslin, M., 1973: Pour une science des religions, Seuil. Paris.

Mutman, M., 2007: "Reciting: the Voice of the Other" in: (eds.) S. Mieszkowski, J. Smith, \& M. de Valck, Sonic Interventions, Editions Rodopi B.V, Amsterdam-New York pp. 103-118.

Mutman, M., 2014: The Politics of Writing Islām: Voicing Difference, Bloomsbury Academic, London - New York.

Prince, G., 1997: "Foreword Palimpsest: Literature in the Second Degree": (ed.) G. Genette, Palimpsest: Literature in the Second Degree, University of Nebraska Press, Lincoln, pp. IX-XI. 
Rhouni, R., 2010: Secular and islamic Feminist Critiques in the Work of Fatima Mernissi, Brill, Leiden.

Rodinson, M., 1974: "The Western image and the Western studies of Islām" in: (eds.) J. Schacht, \& C. Bosworth, The Legacy of Islām, Oxford University Press, Oxford, pp. 9-62.

Roussillon, A., 2005: la pensée islamique contemporaine: acteurs et enjeux, Téraèdre, Paris.

Sabih, J., 2009: "Politisk poesi: Sami S. CHetrit og "Vævet identitet"" in: (eds.) K. Eksell, C. Pedersen, \& W. Scharlipp, Naqd, pp. 51-70.

SANCHEZ, S. J., 2012: L'historiographie du priscillianisme (15592012). From http://sjgsanchez.free.fr/historiogsanchez.pdf,: http://sjgsanchez.free.fr

Sefroui, K., 2013: La revue Souffles 1966-1973: Espoir de révolution culturelle au Maroc, Édition du Sirocco, Casablanca.

Urvoy, D., 1996: Les libres penseurs dans l'Islām classique: L'interrogation sur la religion chez les penseurs arabes independants, Albin Michel, Paris.

Van Ess, J., 1981: "Some fragments of the Mu'āraḍat al-Qur'ān attributed to al/Muqaffa " in: Studia arabica et islamica. Festschrift for Ihāan 'Abbās, pp. 151-163. 